

\title{
Summary of the Seismic Analyses of the Nuclear Fuel Services Reprocessing Plant at West Valley, New York
}

\author{
Elton G. Endebrock
}

Manuscript completed: February 1978

Issued: March 1978

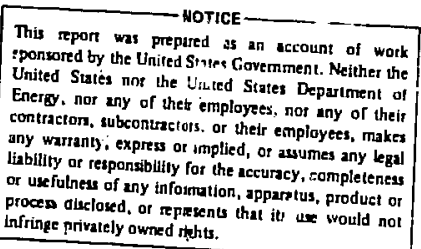


ABSTRACT

BXECUTIVE SUPARY

I. INTRODUCTION

A. Higtorical Sumbary $r$

B. Seiamic Analyses Summaries 2

1. LASL's Analyois 2

2. LLL' a Analysio 3

3. CPD's Analysis 4

II. DISCUSSION OR RESULTS 4.4

A. Introduction $\quad 4$

B. Topicsl Discussions

1. Seiamic Motion Characteriatics

2. Soil-Siructure Interaction

3. Modeling of the Facility

4. Madeling of Nonmonolithic Connections

5. Natural Prequencies

6. Combination of Modal and Spatial Responsea

7. Determination of Stresses or Stress Resultants

8. Pile Distress

9. Parameter Variation Studies

10. Fiberborrd Insulation About the General Purpose Cell

11. Mechanical Crane Room Plexure Distress

12. Process Mechanical Cell and General Purpose Cell

13. Facility Movement

14. Cell Status Summary

a. Acid and Off-Gas Recovery Cell

b. Chemical Process Cell

c. Analytical Gella

d. Equipment tecontamination Roow 9

e. Extraction and Product Purification Cells 9

f. General Purpose Cell 9

8. Liquid Was.te Cell

h. Mechanical Crane Room 10

i. Proceas Mechanical Cell 10

j. Scrap Recovery Cell 10

k. Uranium Product Cell 10

1. Ventilation Wash Room 10

III. COHANTS $\quad 10$

$\begin{array}{lr}\text { IV. MODIFICATIUNS } & 10\end{array}$ 
SUMMARY OF SEISMIC ANALYSES OF THE NUCLEAR FUEL SERVICES REPROCESSING PLANT AT WEST VALLEY, NEW YORK

by

Elton G. Endebrock

\section{ABSTRACT}

Results are presented from the seismic investigations of the Nuciear Fuel Services Fuel Reprocessing Plant conducted by the Chemical Plants Division of Dravo Corporation (CPD), the Los Alamos Scientific Laboratory (LASL), and the Lawrence Livermore Laboratory (LLL). Results of the different analytical procedures are summarized.

The LASL studies showed that atructural distress would initially occur in two places, the building piles and the walls of the Mechanical Crane Room. This structural distress would occur at $0.14 \mathrm{~g}^{\prime} \mathrm{s}$. The LLL investigation showed that she Liquid Waste Cell and the General Purpose Cell would start to show structural distress at $0.09 g^{\prime} s$, and that lateral pile distress would begin at $0.11 \mathrm{~g}^{\prime} \mathrm{s}$.

\section{EXECUTIVE SURMARY}

A seismic analysis of the Nuclear Fuel Services (NFS) Fuel Reprocessing Plant was performed by the Chemical Plants Division (CPD) of Dravo Corporation, Pittsburgh, Pennsylvania; the Los Alamos Scientific Laboratory (LASL), Los Alamos, New Mexico; and the Lawrence Livermore Laboratory (LLL), Livermore, California. This report presents the analytical procedures used by these agencies and the principal results obtained. Also included are discussions delineating the qualitative relations between the reported results and the analytical wethods used. These discussions are based mostly on the seismic investigations of LASL and LLL, with CPD's results and analytical procedures included where appropriate. To CPD it was a desigL problem, whereas to LASL and LLL it vas a problem in analysis. The reports of the LASL, LLL and CPD studies are 1 isted as Refs. $1-4$. The earthquake g-values listed in this report do not imply failure or loss of function of the structural member under consideration but can be considered as representing the point of distress. The g-values correspond to the point at which seismically induced laads or stresses equal the corresponding load or stress limit for the structural member under con- sideration. Seismic loads and stresses wert obtained using an elastic analysis. The loads and stresses representing the point of structural distress of reinforced concrete members were computed using the American Concrete Institute Building Code as a guide. Specially developed methods were used to obtain the structural distress point in the case of piles. Although the word "failure" is used in Refs. $1-3$, the g-values given are identical with the point of structural distress as described above. The loads and stresses computed for seismic loadings were based on a linear analysis; hence, the progression of structural distress could not be determined.

The three agencies made seismic evaluations of the facility confinement structure as it was described in the most recent NFS license application. 5 
The primary atructural distress modes that were identified by the three agencies were pile distress, shear wall distress, and flexure or ahear distress of a cell section.

A summary of the earthquake levels and the general locations at which the impending otructural diatress was predicted are given in Table I. Earthquake leve $1 \mathrm{~g}$ above $0.20 \mathrm{~g}$ 's were not considered.

We concluded that the differences in the scceleration levels at which the NFS confinement atructure vould remain structurally competent are due to the different models, analyais techniques, and fai'ure criteria used by the three agencies. A large percentage of the differences can be explained whenever the conservatism inherent in the various analytical procedures is considered.

\section{INTRODUCTION \\ A. Historical Summary}

Nuclear Fuel Services, Inc. submitted a construction and operating license application to the Huclear Regulacory Commission (NRC) for a modification and expansion of their reprocessing plant at West Valley, New York. The original license issued in 1966 did not require consideration of acceleration levels (other than the Uniform Building Code) in the design for seismic events; however, the present NRC seismic requirements became a consideration for the facility modification. NFS retained the CPD as a consultant to determine the seismic competence of the existing facility and to recommend methods for updating the facility to satisfy updated NRC seismic requirements.

To aid the NRC in the license review, LASL and LLL were asked to provide seismic analyoes of the existing facility. The principal objective was to identify the level of ground motion at which particular structural elements could first experience mechanical distress, LLL and LASL were to conduct independent analyoes but were allowed to exchange information.

LASL and LLL personnel visited CPD for a briefing on the facility structure. Also the NFS West Valley reprocessing plant and site were inspected. Specific information required by LLL and LASL was supplied by NFS and its consultants through drawings, ietters, and private communcations.

B. Seismic Analyses Summaries

1. LASL's Analysis. The LASL seismic evaluation was separated into the distinct tasks of evaluating soil-structure interaction,

TABLE :

SURARY OF RESURTS

\begin{tabular}{|c|c|c|c|c|c|c|}
\hline \multirow{4}{*}{$\begin{array}{l}\text { Substructure or } \\
\text { Structural Heaber }\end{array}$} & \multicolumn{6}{|c|}{ Earthquake Leveln at Iopending Structural Distresa and Locations } \\
\hline & \multicolumn{2}{|l|}{$\mathbf{A}$} & \multicolumn{4}{|c|}{ B } \\
\hline & \multicolumn{2}{|c|}{$\begin{array}{l}\text { Chenica: Planta } \\
\text { Pivioion nf Oravo }\end{array}$} & \multicolumn{2}{|c|}{$\begin{array}{l}\text { Lawrence Livermore } \\
\text { Lahoratory }\end{array}$} & \multicolumn{2}{|c|}{$\begin{array}{c}\text { Los A tamos Scientific } \\
\text { Laboratory }\end{array}$} \\
\hline & Acceleration $\left(\mathrm{g}^{\circ} \mathrm{O}\right)$ & Location & Acceleration $\left.\left(\mathrm{B}^{\prime}\right)^{\prime}\right)$ & Location & Acceleration $\left(\mathrm{B}^{\prime}\right)$ & Location \\
\hline 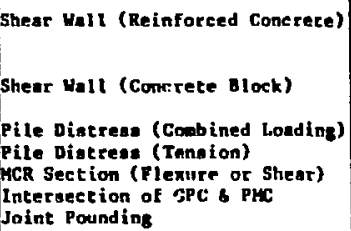 & $\begin{array}{l}\text { D.04* } \\
\text { N.R. } \\
\text { O.08 } \\
\text { O.05 } \\
\text { R.C. } \\
\text { N.R. } \\
\text { P.C. }\end{array}$ & $\begin{array}{l}\text { CPG } \\
- \\
\text { A.R. } \\
\text { EPC }\end{array}$ & $\begin{array}{r}0.09 \\
0.15 \\
0.17 \\
0.03 \\
0.07 \\
0.11 \\
0.17 \\
>0.20 \\
0.20 \\
\text { N.C. }\end{array}$ & $\begin{array}{l}\text { GPC } \\
\text { CPC } \\
\text { LWC } \\
\text { TOP } \\
\text { AOC } \\
\omega * \hbar\end{array}$ & $\begin{array}{l}>0.20 \\
\\
\text { H.C. } \\
0.14 \\
0.16 \\
0.14 \\
>0.20 \\
>0.20\end{array}$ & $\begin{array}{l}\text { N.R. } \\
\text { EPC } \\
\text { HGR } \\
\text { EPC, CPC }\end{array}$ \\
\hline
\end{tabular}

M.R. - Not Reported

M.C. - Mot Considered

EPC - Extraction s Product Purification Celle

CPC - Chemical Proced Cell

GPC - General Purpose Cell

PHC - Procena Kechanical Cell

MCR - Mechanical Crane Roos

AOC - Acid and Orf-Gno Recovery Cell

LAC - Liquid Maste Cell

TOP - Concrete Block Structures on top of CPC

Whains different ansuptions, $0.12 \mathrm{~g}$ comptence level wan ance reported,

H. Dased on CPD's interpratation of steel oplice intenrity in the CPC south wall.

whteriseter of building, the louel at wich loz of piles would he in tension. 
determining overall motion of the confinement structure, and analyzing substructures.

Two-dimensional finite element models of the soil-structure system were developed for use with the code LuSH (described in Ref. 3). Input to LUSH was based on the NRC Design Response Spectra. Foundation-level response spectra were developed from LuSh output data for use in obtaining the seismic response of the confinement structure.

A fixed-base finite element model of the confinement structure was developed using plate elements to represent the walls and threedimensional solid elements to represent the floors and roofs. The weights of heavy equipment and adjacent atructures were represented by appropriately located lumped masses. Connections between adjacent cells were modeled as reslistically as posisible within the constraints of the analytical tools used. The dynami: responses of the confinement structure were obtained using the linear analysis cod: SAP IV (described in Ref. 3) and the foundation-level response spectra developed during the soil-structure interaction analyses. Total structural responses were obtained by first combining the nodal dynamic responses by the square-root-ofthe-sum-of-the-squares method (SRSS) with adjustments for closely spaced modes. The spatial components wer? then combined by the SRSS method.

Several substructures were analyzed to estimate the significant corces acting within them. These forces, or stress resultants, were compared with established or assumed distress criteria for the specific substructure to estimate the earthquake level that would cause structural distress. The substructure forces were obtained from the SRSS acceleration fields and the substructure masses.

The evaluation indicated that the initial structural distress would occu.: almost simultaneously in two different structural elements: the building piles and the Mechanical Crane Room (MCR) walls. Distress was computed to ocrur at $0.14 \mathrm{~g}^{\dagger} \mathrm{s}$.

2. LLL's Analysic. The LLL seismic evaluation was based on a three-dimensional finite element assemblage of plate and membrane elements. The plate elements were used to represent the floors and roofs; the membrane elementa were used to represent the walla. Additional lumped masses were added to appropriate locations to represent adjacent structures and heavy equipment. Rigid connections were used between substructures.

The soil-pile system was modeled as uncoupled horizontal and vertical linear springs. The lateral spring stiffnesses were based on piles emberded in an elastic half́-space with the soil modulus as sumed to vary linearly with depth. The vertical pile stiffness range was based on and-bearing and friction pile behavior. The spring stiffness range for the embedded structures was decerained using bounding estimates from different methods, geometries, and soil properties. The total stiffnesses were divided among the nodes of each embedded structure. The four foundation cases 1 isted below were studied.

CASE 1: Maximum embedded atructure stiffnesa Minimum pile stiffness

CASE 2: Minimum embedded structure stiffness

Maximum pilc stiffness

CASE 3: Minimum embedded structure stiffness Minimum pile stiffness

CASE 4: Maximum embedded structure stiffness Maximum pile stiffness

The structural responses were obtained using the program SAP IV with pre- and postprocessors for plotting and computing maximum shear stresses. Dead luad stresses were computed from s static analysis of the facility. The NRC Design Response Spectrum for $7 \%$ damping was used for horizontal motion input, whereas the vertical input was taken as two-thirds of the horizontal. Total responses were obtained using the SRSS method for combining modal responses and direct addition of the spatial 
components. The earthquake levels at structural diatress were obtained by comparing the computed atresses from dead and seismic loads to the computed stress limits of each element.

Shear wall, pile tension, and pile distress modes were identified. Reported values are bised on the lowest g-value from the four foundation cases atudied. Shear wall diatress was calculated to begin in the Liquid Waste Cell (LwC) and the General Purpose Cell (GPC) at $0.09 g^{\prime} 8$. Lateral load pile distress began at $0.18^{\prime} s$ and pile tension distress began at 0.178 's.

3. CPD's Analysis. CPD represented the facility by using a fixed-base lumped mass and spring model for predicting the structural responses. The mass points were arbitrarily choses and were not related to the torsion, stiffness, or mass centers. Substructures were divided at floor levels, and the mass and stiffness evaluations wer 2 performed independently. The stiffnesses were obtained using finite element assemblages of the substructures. Triangular membrane elements were used to represent the walls, floors, and roofs. They used a code called STRUDL for all the linear static and dynamic analyses.

Structural responses were also obtained using STRUDL. The NRC Vertical and Horizontal Design Response Spectra were applied to the foundation boundary points. The fundamental mode appears to be the only one considered in obtaining the structurai response. The earthquake levels at impending distress were obtained by comparing computed atresses to allowable stresses in some cases and by comparing seismically produced stress resultants to computed ultimate stress resultants in other cases.

Using present NRC guidelines, CPD calculated that the MFS facility would withstand an earthquake acceleration of $0.04 \mathrm{~g}^{\prime} \mathrm{g} \pm 0.01 \mathrm{~g}$ 's . The first element calculated to show structural distress was reported to be the south wall of the Chemical Process Cell (CPC). The pile loading and shear wall loading were discussed qualitatively in some detail.
II. DISCUSSION OF ReSULTS

A. Introduction

This oection contains a more detailed description of the methods uged by each agency in its treatment of specific topics. Also included are discussions to account qualitatively for the differences in results obtained by each agency. The discussions are mostly about LLL's and LASL's investigations. Since CPU's approach was from a design viewpoint rather than an analytical viewpoint, its results are not always comparable.

B. Topical Discussions

1. Seismic Motion Characteristics.

The three agencies used the MRC Design Response Spectra as the basis for defining the site seismic motion characteristics. However, different damping values were used, and the application of the response spectra differed. CPD applied both the horizontal and vertical NRC Design Response Spectrs modified 'for :47 damping to its structural model. LLL applied the NRC horizontal response spectrum for $7 \%$ damping directly to its structural model. The LLL vertical response spectrum was taken as twothirds of the horizontal response spectrum.

LASL considered the NRC response spectra as defining the site free-field seismic motion characteristics. Compatible bedrock motions were obtained for tive undereloped site. Then, with the structure and piles on the site, foundation-level response spectra for $7 \%$ damping were developed using tha code LUSH with the bedrock motions as input. The developed foundation-level response spectra were combined into a single vertical and a single horizontal response spectrum.

LASL' s soil-gtructure investigations resulted in a horizontal response spectrum that enveloped the corresponding NRC response spectrum by about $20 \%$ over the frequency range from 1 to $33 \mathrm{~Hz}$. The LASL vertical reaponse spectrum showed a peak acceleration response of $3.0 \mathrm{~g}$ 's at a Erequency of $6.2 \mathrm{~Hz}$; however, for the structure frequencies, the maximum vertical acceleration response was approximately $0.78 g^{\prime} s$. 
LASL's horizontal and vertical oeismic motion inputs vere therefore more severe than LLL's.

2. Soil-Structure Interaction. Both

LLL and CPD represented the soil and soil-pile system as linear uncoupled springs. CPD provides an extensive discussion on soil-pile spring stiffness effects, but detuils for determining the spring stiffnesses and the values chtained are lacking.

LhL used two methods for determining the lateral soil-pile spring stiffnesses along with a bounding range of soil parameters. The amallest and largest stiffne: ses obtained were used in the seismic analysio. The range for the vertical pile stiffnesses was based on a bounding range of soil parameters and the behavior of end-bearing and friction piles. The soil spring stiffnessea for the embedded cells were obtained by bounding estimates that considered different geometries, methods, and soil properties.

LASL modeled the soil-pile structure system using finite elements. Special considerations were required to transform from a three-dimensions 1 facility to two two-dimensional plane-strain soil models. The soil, pile, and structural systems were idealized, and the material properties for the two-dimensional models were obtained by considering geometries and material properties of the three-dimensional facility. Attempts were made to maintain a one-to-one correspondence between the parameters important in a dynamic analysis. No special techniquea were required to obtain dynamic effects of the soil on the modeled embedded cells, LASL did not consider bounds on the soil properties but used values that were described as the best available for the site.

LLL's method for modeling the soil-pilestructure system allows for the direct determination of rocking, translational, and torsional vibration modes and an estimation of the resulting responses. The response spectra method was used to obtain the structural responses, and modal damping was not modified for the soil-structure related modes since SAP IV accepts a single damping value only. Structural responses are overestimated if soil-structurerelated modal damping is not modified.

The two-dimensional models used by LASL eliminate the soil-structure-related torsional effects. Rocking and translational effects wers also excluded directly from tise analyses since SAP IV uses only a single response spectrun for a given coordinate direction. Torsion of cells and structural elements relative to the fixedbase structural mojel is included and is evident frow the mode sliapes.

3. Modeling of the Facility. CPD did not report many detaila regarding its facility model, though some information became available at meetings. We know that CPD used a lumped mass and spring model of the facility and that finite element models of substructures were developed to determine the spring stiffnesses. Triangular membrane elements were used to represen: the wa1ls, floors, and roofs. The procedures for determining the masses and for determining forces or stresses within the structural elements were not reported.

Both LLL and LASL used SAP IV to

determine the structural responses, and both used a finite element model of the confinement structure. However, the types of elements used by the two agencies differed. LLL used plane stress membrane elements to represent the walls, and plate elements to represent the roofs and floors. LASL used three-dimensional solid elements to represent the roofs and floors, and plate elements to repreaent the walls:

The type of element used will influence the calculated seismic response of the structure. Simulating the individual cell structure walls with membrane elements impicity presumes that all resistance to motion is developed in the plane of the walls only. This assumption is valid for cells that have aspect ratios near unity; however, several cells in the NFS Facility (the GPC, CPC, and Process Mechanicel Cell (PMC)) are relatively loig and narrow and have thick walls. LAST, found that, for these cella, the forces that 
have components acting perpendicular to the plane of the valls produce resistance that can dominute the resista tee developed by the forces in the planes of the walls. For the GRC, the out-of-plane resistance could be as high as two-thirds of the total cell resistance in the diraction norma? to the long dimention of the cell. The use of wembrane elements would therefore lead to the prediction of ghear wall

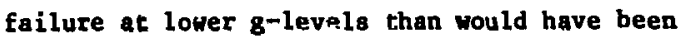
obtained using plate elements. In LASL's mode1, the rotational degrees of freedom of the nodal points vere deleted. This prevents rotations at the intergections of the walls with the roofs and floors and leads to a minor overestimate of the structural stiffnesses and a minor underestimate of the shear forces in the shear wa118.

LLC used artificially otiff plate elements to eliminate local oscillations of the fl,wra end roofs. This common practice effuctively caused the floors and roofs to act as rigid diaphragms. LASL did not find it necessary to atiffen elements to eliminate local oscillations. The floors and roofs of the facilicy are massive; thus, the otiffening of the roof $a$ and floors probably did not result in any significant differences in responses. CPD's use of membrane elements also resulted in underestimating the structural atiffnesses and overestimating the shear forces in the shear walls.

\section{Modeling of Nonmonolithic}

Connections. A number of cells in this facility are not connected to each other in the usual structural sense. Instead, they have a joint consisting of a slab that is recessed into a wa11, rests on the recess, and is separated from the wall by a layer of material called Rodofoam. This type of connecicion does not develop a stiffneas in any direction until the relative motion between the connecting parts becomes large enough to close the gap. Significant tensile forces cannot develop, but conpressive farces may develop upon contact between the wallo and slabs.

Although the force-displacement relationships of these connections exhibit nonlinear behavicr, a linear model of the connection behavior was necessary for analyais. Therefore, IASI modeled these connections using linear truss eletnents that have defined axisl stiffness. The modeled connections did not exactly simulate the beha ior of the actual connections since they could develop both compressive and tensile forces. However, they did provide for a degree of flexibility between the counecting parts. LLL, LASL, and NRC personnel agreed in $a$ joint meeting that LLl would model these connections as being rigid while LASL would model them as being flexible. The relative effects of modeling these connections differently is unknown and cannot be deterained from LLL's and LASL's present investigations.

LASL performed some computations in which the connections were considered as both monolithic and nonmonolithic. When they were considered as monolithic, the lowest natural frequency was associated with metions of the Extraction and Product Purification Cells (EPC). When they were considered as being nonmonolithic, the lowest natural frequency was associated with motions of the Analytical Cells (AC), LWC, and the Ventilation Wash Room (VWR). The natural frequency of the EPC was lover than that of the $\mathrm{AC}$.

\section{Natural Frequencies. The only} natural frequencies reported by CPD were 2.5 and $3.5 \mathrm{~Hz}$. These were raported to be the fundamental frequencies in the horizontal and vertical directions, respectively, and were the only ones considered in obtaining the structural responses. Note that the above-mentioned natural frequencies correspond to the peaks of the NRC horizontal and vertical response spectra, respectively.

LLL obtaingd the 10 lowest natural frequencies and corresponding mode shares for its soil-pile-structure system model. The lowest frequency obtained was about $2 \mathrm{~Hz}$ and the highest was about $16 \mathrm{~Hz}$; this range includes all foundation cases considered by LLL. These two extreme values did not occur in the same case, but represent the bounds on all cases considered. The lowest three frequencies are 
associated with soil-structure interaction and correspond to rocking and torsional motions of t.t $\Rightarrow$ facility. The difference in response caused by including modes with frequencies above $16 \mathrm{~Hz}$ was $x$ eported to be small.

LASL obtained the lowest 24 natural frequencies and their corresponding mode shapes. The lowest scructural frequency was about $12 \mathrm{~Hz}$ and the highest was about $33 \mathrm{Hx}$. Many of the frequencies were closely spaced. This set of frequencies did not include those related to the soil-structure system. Soilpile-strusture natural frequencies ranging from $\mathrm{l}$ to $7 \mathrm{~Hz}$ were tpparent from the analyaes. However, because a fixed-base atructural model was used, friquenties below $12 \mathrm{~Hz}$ were not used directly in calculating the structural responses.

\section{Combination of Modal and Spatial}

Responses. CPD used only the fundamental frequencies, and no modal responses were combined. Spatial components were combined by the SRSS method.

LL combined modal responses using the SRSS method. No adjustments for close frequencies were made. The spatial components were combined using direct addition.

LASL also used the SRSS method for combining modal responses; however, adjustments were made for close frequencies. Spatial components were combined using the SRSS method.

Direct addition of spatial components leads to slightly more severe structural responses than does the SRSS method.

\section{Determination of Stresses or}

Stress Resultants. The method that CPD used to determine stresses or stress resultants is unknown.

In estimating shear wall failures, iLL computed the maximum shear otresses at the centroidp of the membrane elements from the normal and shear stresses obtained directly from SAP IV. Distress was the'n determined using the largest maximum shear stress value at these points from the four foundation cases. In determining the condition of a particular shear wa11, the moximum shear stress from dead and seismic loads was compared to its ultimate shear stress, Ultimate shear stress was based on the concrete properties and the amount of steel reinforcing in cach element. Pile loads were obtained by adding dead weight and seismic contributions.

LASL used resultant forces in all cases for estimating distress of structural elements. The use of plate elements yields centroidal forces and moments directly from SAP IV; however, these values were not used exclusively. Stress resultauta were also obtained from force fields that were computed using the SRSS acceleration fields and the weight distributions of the substructures or structural elements.

The LLL and LASL models of the facility possessed rather coarse finite element grids. The accuracy of frequencies, displacements, stress resultante, and accelerations are not as atrongly dependent upon the finite element grid size ss are the stresges.

8. Pile Distress. Pile distress was a primary consideration of all the agencies. They were in complete agreement regar ing the possible distress modes associated with piles. Pile tension and the combination of a compressive axial load with a lateral pile cap load were identified as the possible distress modes. There was little disagreement on criterit for pile tension distress, but the criteria used by each agency for determining the comtination loading distress differed. The latoral loada and the vertical compressive load are time dependent and do not necessarily attain their maximum values simultaneously. As a result, the definition of pile distress is elusive, and an accurate assessment of the distress definition is possible only for very specialized cases.

CPD considered a pile to have reached its loading 1 mit when the axial compressive load reached $250 \mathrm{kips}$. This value was based on $90 \%$ of the static capacity as obtained from a load test. The allowable maximum lateral load was taken to be $16 \mathrm{kips}$. This value wao arbitrarily selected as $6.67 \%$ of the vertical allowable capacity. CPD did not consider lateral and 
vertical load combinations for determining

loading limits.

Lut deterwined pile integrity by

combining dead load atresses on the piles with bending atresses produced by lateral loads. This combination vas determined separately for each lateral load. These combined stresses vere then compared with pile yield atress.

LASL's pile distress criteria were based on the sass of the ratios of the acting loads to their correaponding computes ultimate lasds. Impending distress was considered to have occurred whenever the SRSS of the load ratios became unity. The load ratios used were $P_{a} / P_{u}, H_{a e} / M_{u e}$, and $M_{a n} / M_{u n}$, where $\underline{P}$ refers to axial loads, $\underline{M}$ refers to bending moments, a

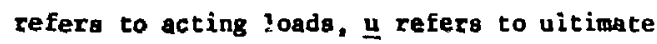
loads, $a$ refers to the $\mathbb{N}-S$ direction, and $\underline{e}$ refers to the $E-W$ direction.

Since little information is available in the literature on the behavior of piles during earthquakes, this report will make no judgment on the relative merits of combined load pile diatreas criteria.

Although the piles under the facility were not designed to resist tensile forces, the linear structural models used by all the agencies necessarily yielded tensile forces whenever the upward earthquake inertial forces exceeded the dead load on the piles. Pile tension was not considered as failure of the piles themselves, but $a s$ an indicator of the point at wich the elastic solutions were no longer valid. The consequences of pile tension could not be properly evaluated since the model solution was no longer valid. Uplift introduces nonlinearities and only linear solutions could be accommodated.

Both LLL and CPD used the percentage of piles in tension as a measure of the validity of their linear solution. LASL found that pile tension or uplift began at an earthquake level of $0.16 g^{\prime} s$ and LLL determined pile distress to occur at $0.17 \mathrm{~g}$ 's (level at which $10 \mathrm{z}$ of the piles are in tension). For pile tension commencing at this level, overturning of individual cells was not considered to be a primary distress mode for earthquake leve 18 below $0.20 \mathrm{~g}$ 's.

9. Parameter Variation Studieg. None of the agenciea performed a complete parameter variation study to determine the limits of their results. When limits were given, their bases were not reported. All of the agencies did conduct limited parameter variation studies. CPD's model sas ured with and without soil embedment springs.

Because of the limited information available for determining spring otiffness:s for a soil-pile system, LLL considered different geometries, methods, and soil properties to obtain bounds.

LASL perforned a paramecer variation study in one case. In the soil-structure investigations, the pile lateral stiffnesses were varif:! from zero (no piles) to about 140 times the average pile stiffnesses. We determined that there were only small differences in the foundation response spectra in the rarse of the structure natural frequencies.

10. Fiberboard Insulation About the General Purpose Cell. The fiberboard insulation placed between the GPC walls and the surrounding soil is one-half inch thick. LLL, LASL, and NRC personnel agreed that the state of soundness or deterioration of this insulation would not greatly affect the response of the structure; consequently, it was not further considered.

\section{Mechanical Crane Room Flexure}

Distres6. The MCR is monolithically connected to the PMC on one end and supported by two columns at the other end. LASL's structural response solution indicated large accelerations in the MCR, which is the north section of the PMC. The roof of the MCR is removable so the structurally significant cross section of the room is $U$-shaped. The bending moment and the shear force at structural distress occurred at an earthquake level of $0.14 \mathrm{~g}^{\prime} \mathrm{s}$.

Neither CPD nor LLL reported this type of structural distress.

12. Process Mechanical Cell and

General Purpose Cell. The intergection of the PMC and the GPC appeared to be a weak link from 
the facility drawings. It vas investigated by both LLL and WASL. Both determined that

atructural diatress did not occur for earthquake levels below 0.208 's.

13. Facility Movement. There vas agreement between LASL, LLL, and NRC personnel that movement of the facility downill during an earthquake would be prevented by the piles and the buried cells.

\section{Cell Statua Sumpary. The}

earthquake levela listed belou for each confinement cell vere taken as the lower of the values reported by LASL and LLL. Pile distress values reported are for the first pile group under exch cell that experienced distress. Unless otherwise noted, the listed g-values below $0.20 \mathrm{~g}$ 's were computed by LLL.

a. Acid and Off-Gas Recovery Cell.

Parts of the Acid and Off-Gas Recovery Cell (AOC) are enclosed by concrete block walls whose shear strength is low compared to that of reinforced concrete valls. The onset of concrete block shear wall distress was predicted to occur at an earthquake level of $0.07 g$ 's. The part of this cell that depends upon concrete block walls for confinement could fail below $0.20 \mathrm{~g}$ 's. Pile tension distress was predicted to occur at $0.14 \mathrm{~g} ' 8$, lateral pile distress was predicted to occur at $0.11 \mathrm{~g}^{\prime} \mathrm{s}$.

b. Chemical Process Cell. This is a reinforced concrete cell closed with a shielding door. A steel frame and coacrete block wall structure on the top of the CPC houses the shielding door when it is in the open pesition. Shear wall distres? in this concrete block could be initiated at $0.03 \mathrm{~g}$ 's. But the shielding door would normally be closed during operation, so the confinement integrity would be maintained. Reinforced soncrete shear wall distress was predicted to oceur at $0.15 g^{\prime} s$ in a wall section that is located above grade. According to CPD's interpretation of the CPC drawings, the reinforcing steel oplice lengths in the south wall are inadequate. We do not know if this error was corrected during construction. If not, the eurthquake level for reinforced concrete shear wall distress could be less than reported
- above. Pile tension and lateral pile distress vere predicted to occur at earthquake levels of $0.18_{\mathrm{g}}$ 's and $0.1 \mathrm{~g}^{\prime} \mathrm{g}$, respectively.

c. Analytical Cells. This otructure vas found to be seismically competent for earthquake levels below $0.20 g^{\prime} B$; however, if the LWC and VwR fail belou $0.20 \mathrm{~g}^{\prime} \mathrm{s}$, the analytical cell could be damaged.

\section{d. Equipment Decontamination Room.}

In the Equipment Decontamination Room (EDR), shear wall distreas was not predicted for earthquake levela bclow $0.20 \mathrm{~g}$ 'B. Pile tension and lateral pile distress were found to occur at 0.13 and $0.07 g^{\prime} 8$, respectively.

\section{e. Extraction and Product Purifi-}

cation Celle, Shear wall distress in the EPC is not predicted for earthquake levels below $0,20 \mathrm{~g}$ ' 8 . Pile tension distress was found to occur at $0.14 \mathrm{~g}^{\prime} \mathrm{B}$, Lateral pile impending distress occurs at $0.13_{\mathrm{B}}{ }^{\prime} \mathrm{B}$. This cell is the tallest confinement structure in the facility, but we concluded that overturning was not a major concern for earthquake levels below $0.20 g^{\prime} 8$ (LASL). A nonmonolithic connection exists between the EPC and the CPC. Serious pounding at this joint is not anticipated below $0.20 \mathrm{~g}$ 's (LASL). However, piping cornecting the EPC with the other cells could be damaged at lower earthquake levels.

f. General Purpose Cell. This cell is completely buried. Shear wall impending distress occurs in the west wall at $0.09 \mathrm{~g}^{\prime} \mathrm{s}$. Because this cell is buried, canfinement would not be compromised if the wall cracked. The soil surrounding the cell is quite impervious, and radioactive products probably vould not aigrate to a great extent within the soil mas. Lateral pile distress begins at $0.05 \mathrm{~g}^{\prime} \mathrm{s}$, and pile tension distress occurs at $0.11 \mathrm{~g}^{\prime} \mathrm{s}$.

B. Liquid Waste Cell. This cell is partially buried, and the waste is in liquid form. Shear wall distress is predicted to occur at $0.17_{\mathrm{B}} \mathrm{s}$. Since the cell is lined with stainless ateel sheeting, a penetrating crack in the concrete valls would not necessarily destroy their confinement integrity. Lateral pile distress occurs at $0.10_{\mathrm{g}}{ }^{\prime} \mathrm{g}$. Pile tension distress 
does not occur for earthquake levels below $0.208^{\prime} 8$.

h. Mechenical Erane Roon. This room is discusaed in conjunction with the PMC.

i. Process Mechanical Ce11. The MCR forms the north end of the PuC. The MCR was designed for storage and anintenance of the traveling crane that servicea the PMC. It is aeparated from the remainder of the PKC by a heavy ohielding door that is norwally clased during operation of the cell. It was determined by LASt that the MCR could completely aeparate from the PuC at a section north of the shielding door at $0.14 \mathrm{~g}^{\prime} \mathrm{g}$ (LASL). However, confinement integrity of the hot part of the rwC would be mintained if tbe ahielding door was closed. Shear vall distress in the PXC and direct obear distres: between the PMC and the GPC are not predicted for earthquake levels be low $0.20 \mathrm{~g}{ }^{\prime} \mathrm{B}$. Pile tenaion diatrese occurs at $0.12 \mathrm{~g}^{\prime} \mathrm{s}$ and lateral pile distress occurs at $0.13 \mathrm{~g} ' s$.

\section{i: Scrap Recovery Ce11. The Scrap}

Recovery Cell (SRC) is monolithically attached to the CPC and could therefore be considered a part of the CRC. From earthquake levels below $0.20 \mathrm{~g} s$, no structural distress vas predicted in this cell.

k. Uranium Product Cell. Shear wall distzess was not predicted for earthquake levels below $0.20_{\mathrm{g}} \mathrm{s}$ in the Uranium Product Cell (UPC). Lateral pile distress occurs in this cell at $0.12 \mathrm{~g}^{\prime} \mathrm{s}$, and pile tension distress occurs at $0.13 \mathrm{~g}^{\prime} \mathrm{s}$.

1. Ventilation Wash Room. Structural distress was not predicted for this room for earthquake levels below $0.20 \mathrm{~g}$ 's.

III. COMENTS

Special conditions were encountered in this evaluation that are not norwally features of atructure abjected to a dynamic analysis. The confinement structure included thick-walled asymetrical cells that were also asymetrically located relative to each other. Cells were located both above grade and belou grade (buried), and interfaces between cells were both monolithic and nonmonolithic. Although the investigations were atute-of-the-art, the complexity of the facility caused differences in the seimic analytical approaches and results. In this report attempto have been made to indicate the specific analysis or comptrational procedures used that led to different resulte. IASL attempted to balance the amount of conservatism inherent in che analytical methods so that a large factor of afety did not accumlate. Lhl also recognized inherent conservatiom in some of the computational methods and removed it wherever possible. CPD included safety factors based on current regulatory guidelines in each step of ita analyois, thus leading to a large safety margin in the final result.

The investigations only addressed the onset of structural distress and did not attempt to include progressive structural distress. Hote that otructural distress is very different from confinement atructure failure. Confinement Btructure failure accurs when radioactive products can be released to the enviroment; this type of failure is not addressed here. The significance of the structural distress types identified in these investigations is discusaed below.

1. Pile Tension Distress. The pile caps vere not designed to resist tension, and during an earthquake, cells may lift off the piles. The linear aolutions used in the invartigations made it necessary to include pile tension forces. Pile tension is not a crucial failure mode in that it does not necessarily result in penetrating cracks in the cells, but it moy lead to them. The existence of pile tension was used by LLL as an indicator of the validity of their linear solution since pile tension or uplift results in nonl ineat behavior. In discussions NRC, LLl, and LASL decided that elastic analyois would be valid up to the point where $15 \%$ of the piles wure in tension.

2. Lateral Load Pile Distreas. Whenever combined lateral and vertical loads acting at the pile caps $r \in B c h$ certain magnitudes, the piles yield. The beginning of pile 
yielding also indicates the start of the nonlinear regime. Yielding of the piles does not directly result in $108 s$ of cell confinement integrity but may lead to the overstressing of cell parts or structural elements. The pile yielding could also aid in reducing the structural response in that more energy is dissipated.

\section{Shear Wall Distress. Shear wall} distress could result in a penetrating crack with possible loss of confinement integrity. Once a crack forms, load cycling will probably lead to a rapid progression of cracking. The shear walls that were identified to be among the first to reach structural distress are dominated by shear forces rather than flexural forces. These shear walls could not be expected to exhibit ductile behavior. Consequently, in considering confinement integrity of the cells, shear wall failure could lead to loss of confinement.

\section{Ce11 Section Flexure Distress.}

This type of structural distress was found to be likely only in the MCR. It could leau to a complete collapse of the cell section since the maximum elastic moment is greater than its ultimate moment capacity. The potential for releasing significant amounts of radioactive materials is small since the crucial section is not a part of a hot cell.

\section{MODIF ICATIONS}

The possibility of modifying the reprocessing plant to increase its seismic competence was considered briefly. The structural elements that are among the first to become distressed are not always acceosible, so modifications would be costly, if not impossible. All agencies agreed that any major modification wruld be impractical, though in certain cases minor modifications may be feasible. Construction of new cells to gerye particular functions would bs more practical than attempting to upgrade the existing cells. RREBRENCES

1. R. C. Hurray, T. A. Nelson, and A. M. Davito, "Seismic Analysis of the Nuclear Fuel Service Reprocessing Plant at West Valley, New York," Lawrence Livermore Laboratory report UCRL-52266 (May 24, 1977).

2. R. C. Murray, T. A. Nelson, and A. M. Davito, "Seismic Analysis of the Nuclear Fuel Service Reprocessing Plant at West Valley, New York: Documentation," Lawrence Livermore Laboratory report UCID-17453 (April 26, 1977).

3. E. G. Endebrock, Robert J. Bartholomew, Joel G. Bennett, Robert I. Brasier, and william F. Corcoran, "Seismic Investigation of the Nuc lear Fuel Services, Inc. Reprocessing Plant at West Valley, New York," Los Alamos Scientifi: Laboratory report LA-7087-MS (February 1978).

4. Seismic Competence of the Existing Process Building at the West Valley Reprocessing Plant. Cheraical Plants Division, Dravo Corporation, Pittsburgh, Pennsylvania report No. 0476.015 (June 1976) NRC Docket No. 50-201.

5. Application for Amendments to Provisional Operating License No. CSF-1 for the NFS West Val ley Reprocessing Facility, Volume 1, Nuclear Fuel Services, lac., Rockville, Maryland (1974), Docket No. 50-201. 